\title{
The effect of raw material combination, yarn count, fabric structure and loop length on the thermal properties of Eri silk bi-layer knitted fabrics
}

DOI: $10.35530 / I T .072 .03 .202032$

SENTHIL B. KUMAR

RAMESH M. KUMAR

\section{ABSTRACT - REZUMAT \\ The effect of raw material combination, yarn count, fabric structure and loop length on the thermal properties of Eri silk bi-layer knitted fabrics}

Eri silk is one of the wild silk varieties which are mainly available in the north-eastern areas of India. It exhibits good mechanical and thermal resistance properties. In this concern, the present study focused to develop a bi-layer knitted structure made from Eri silk yarn as one side(next to skin) and on another side bamboo yarn knitted fabric. Similarly, Tencel knitted fabric was used instead of bamboo. Twenty-four bi-layer knitted fabrics were developed and then analysed for its thermal comfort property. The air permeability, and wick-ability were found to be higher and the thermal resistance was found to be higher for bi-layer plated interlocked knitted fabric made out of Eri silk compared to bamboo and Tencel.

Keywords: bamboo, Eri silk, Tencel, thermal resistance, thermal conductivity

Influența combinației de materii prime, finețea firelor, structura tricotului și lungimea buclei asupra proprietăților termice ale tricoturilor dublu strat din mătase Eri

Mătasea Eri reprezintă unul dintre tipurile de mătase sălbatică disponibile în principal în zonele de nord-est ale Indiei. Aceasta prezintă proprietăți de rezistență mecanică și termică. În acest scop, studiul de față s-a concentrat asupra dezvoltării unei structuri tricotate dublu strat, realizată din fire din mătase Eri, pe o parte (în contact cu pielea) și pe cealaltă parte, din fire din bambus. În mod similar, a fost utilizat Tencel-ul în locul bambusului. Au fost dezvoltate 24 de tricoturi dublu strat și apoi analizate din punctul de vedere al proprietăților de confort termic. S-a constatat că permeabilitatea la aer, capacitatea de absorbție și rezistența termică sunt mai ridicate pentru tricoturile interlock dublu strat din mătase Eri, comparativ cu bambusul și Tencel-ul.

Cuvinte-cheie: bambus, mătase Eri, Tencel, rezistență termică, conductivitate termică

\section{INTRODUCTION}

The main purpose of clothing is to maintain normal body temperature and to protect the body against varying external conditions. Thermal insulation is defined as the effectiveness of a fabric in maintaining a normal temperature of a human body under equilibrium conditions. Thermal insulation of fabrics depends largely on the thickness of the fabric and it is independent of the fibre material [1]. The capillary structure and surface properties of yarns are linked to heat transfer [2].The thermal conductivity decreases with increasing material density $[1,3]$. The entire three thermal resistant properties transfer the heat from the human body to an environment [4]. The performance of layered fabric in thermo-physiological regulation is better than for a single layer structure [5-9].

Hydrophilic fibres like viscose can absorb liquids into the fibre structure thus preventing the spread of liquids, including sweat, along the fabrics [10]. The thermal resistance of multi-layered fabrics increases with increase of mass per unit area [11]. The moisture content of one layer is not only dependent on its material properties but also on the comfort properties of neighbouring layer [10]. Blending wool with polyester or wool with bamboo has improved comfort properties of the fabrics in comparison to $100 \%$ wool and $100 \%$ bamboo fabrics [12]. The double layer knitted structures were developed where the inner (contact) layer is made of polypropylene yarns and the outer layer is made of cotton or viscose yarns [13]. Due to various micro-gaps and micro-holes in crosssection of bamboo fibre, it has better wicking ability than modal yarn [14]. Eri silk has better softness compared to other silk materials. It also possesses better thermal insulating properties than wool and higher comfort than cotton and mulberry silk [15-17]. Utilization of knitted fabrics for functional garments is emerging, as it provides better comfort, good extensibility, shape retention to the body and soft feel, as well as being of lightweight, with wrinkle resistance and ease of care. Knitted structures provide good thermal and moisture management properties for active applications [18].

Eri silk has unique thermal, physical and moisture management characteristics when compared to other commercial silk varieties [19-21]. Eri silk knitted structures with coarser yarn and tighter stitch length 
gives higher thermal absorption, thereby providing cool feeling on initial skin contact. Eri silk knitted fabric has good comfort properties, which confirms its suitability for light winter active applications. It is expected that knitted fabric produced from these yarns has good demand in the international market because Eri silk fabric is produced by non-violent methods (without killing silk worm) and has better dimensional, thermal and wicking properties [15]. Eri fibre possesses unique dual nature with excellent strength and softness properties of silk fibre coupled with warmth properties similar to wool fibres [22]. Eri silk is known for its excellent strength, soft-smooth feel, comfort and lustre besides having good thermal behaviour [23]. The Eri fabric is an excellent material for shirting, suiting, bed spreads, curtains and other furnishings and it possesses excellent dimensional and thermo-physiological comfort properties [24]. The thermal conductivity of knitted fabrics reduces as the proportion of bamboo fibre increases in the thermal radioactive properties of penguin down and yarn [25]. The bamboo and cotton double knitted fabrics have the least water vapour and thermal resistance values when compared to other bi-layer fabrics [26].

\section{MATERIALS AND METHODS}

\section{Yarn selection}

Eri silk yarn was procured from Eco Tasar silk Pvt Ltd, New Delhi, India. Bamboo, Tencel and micro denier polyester were procured from Ganapathi Chettiar yarn agency, Tirupur, Tamilnadu, India. The physical parameters of Eri silk yarn, bamboo, Tencel samples yarn count was measured according to American Society for Testing and Materials D1907-01 standard and single yarn strength was evaluated by using Instron strength tester as per American Society for Testing and Materials D2256 standard. The evenness parameters were measured as per American
Society for Testing and Materials D1425 M: 14 method by using USTER evenness tester UT 5. Table 1 shows the various yarn characteristics.

\section{Fabric production}

In this research an idea has been made to analyse thermal properties of Eri silk bi-layer knitted fabrics blended with bamboo and Tencel yarns. Eri silk yarns and bamboo yarns were selected on either side for constructing bi-layer knitted fabrics and bamboo was replaced by Tencel yarn for conducting the investigation:

- Eri silk and bamboo yarns were used to make plated interlock, mini flat rib and flat back rib knitted fabric.

- Eri silk and Tencel yarns were used to make plated interlock, mini flat rib and flat back rib knitted fabric. The bi-layer knitted structures were prepared using 16.7 Tex and 14.3 Tex for Eri silk, 19.7 Tex and 14.8 Tex for bamboo and Tencel. All samples were produced in circular multi-track weft knitting machine (Keumyong knitting machine) with 34 inches diameter, 82 feeders, 18 gauge and 3840 needles. In this experimental work, the bi-layer fabric was developed in which the outer layer is made of bamboo and Tencel that is regenerated cellulosic fibres. The inner (next to skin) layer is made up of Eri silk fibre. The yarn which has to form an outer layer is fed into the dial needle and as an inner layer is fed into the cylinder needle. Plated interlock, mini flat rib and flat back rib knitted fabrics were produced using two different yarn counts and two different loop lengths. The visual appearances of the stitch diagrams are mentioned in figure 1.

\section{TEST RESULTS AND DISCUSSION}

The fabric produced with different count of yarns, structures and loop length combinations were inves-

\begin{tabular}{|c|c|c|c|c|c|c|c|}
\hline \multicolumn{8}{|c|}{ YARN CHARACTERISTICS } \\
\hline $\begin{array}{c}\text { Test } \\
\text { particulars }\end{array}$ & $\begin{array}{l}\text { Eri silk- } \\
\text { 16.7 Tex }\end{array}$ & $\begin{array}{l}\text { Eri silk- } \\
\text { 14.3 Tex }\end{array}$ & $\begin{array}{c}\text { Micro denier } \\
\text { polyester- } \\
155 \text { denier } \\
\text { (binding yarn) }\end{array}$ & $\begin{array}{l}\text { Bamboo- } \\
\text { 14.8 Tex }\end{array}$ & $\begin{array}{l}\text { Bamboo- } \\
\text { 19.7 Tex }\end{array}$ & $\begin{array}{l}\text { Tencel- } \\
\text { 14.8 Tex }\end{array}$ & $\begin{array}{l}\text { Tencel- } \\
19.7 \text { Tex }\end{array}$ \\
\hline Average count in Tex & 18.00 & 14.99 & 17.33 & 15.27 & 19.67 & 14.00 & 19.61 \\
\hline Count CV\% & 5.37 & 4.11 & 0.42 & 1.07 & 0.7 & 1.83 & 0.79 \\
\hline Strength & 66.7 & 116.1 & 170 & 60.6 & 88.8 & 80.3 & 128.2 \\
\hline Strength CV\% & 9.93 & 3.54 & 2.56 & 2.57 & 8.9 & 6.67 & 3.41 \\
\hline CSP - Count Strength Product & 2186 & 4568 & 5786 & 2340 & 2662 & 3384 & 3857 \\
\hline Unevenness U\% & 18.86 & 9.79 & 1.34 & 10.04 & 9.25 & 10.62 & 9.63 \\
\hline Thin/1000 m (-50\%) & 493 & 0 & 0.5 & 0.5 & 0 & 12 & 1 \\
\hline Thick/1000 m (+50\%) & 1751 & 61 & 3 & 14 & 6 & 24.5 & 16 \\
\hline Neps/1000 m (+200 \%) & 2038 & 32 & 5 & 11.5 & 10.5 & 35.5 & 22.5 \\
\hline IPI - Total Imperfections & 4282 & 93 & 9 & 26 & 17 & 72 & 40 \\
\hline Hairiness & 4.39 & 4.84 & 7.3 & 11.5 & 6.06 & 5.69 & 8.02 \\
\hline TPI - Twist per inch & 22.50 & 23.40 & 33.10 & 21.30 & 18.80 & 22.50 & 17.60 \\
\hline
\end{tabular}




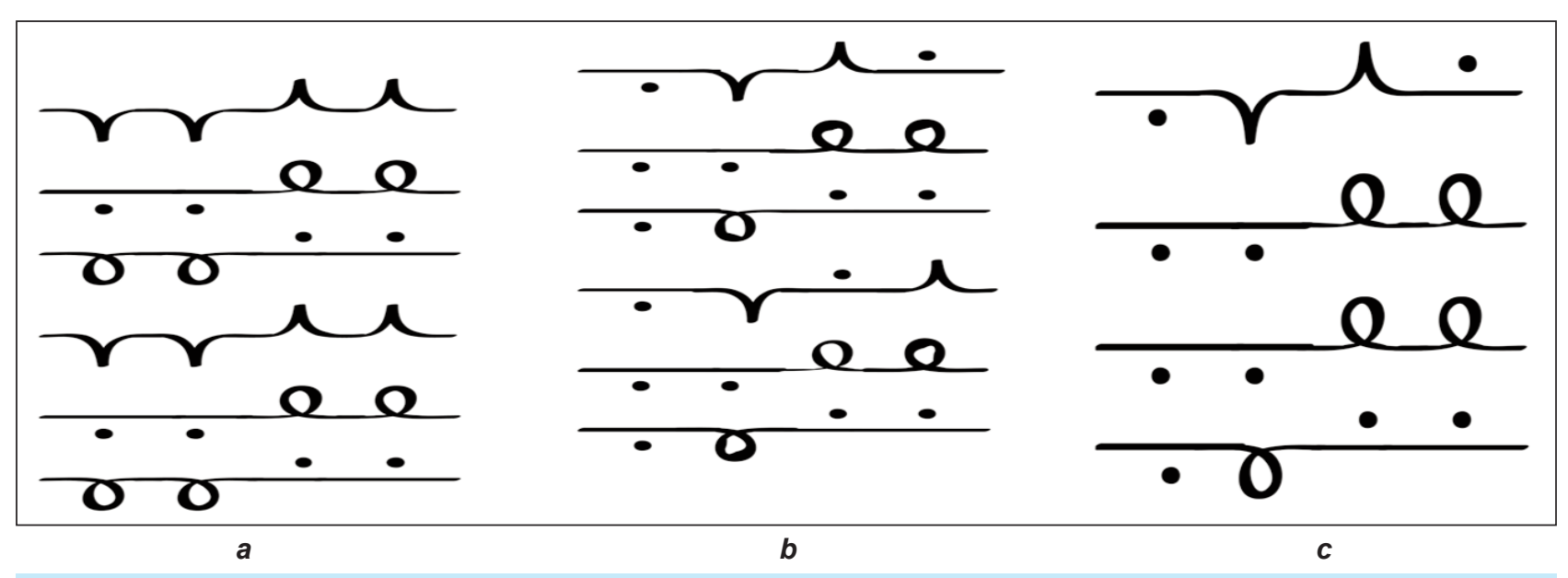

Fig. 1. Plated interlock, mini flat back rib and flat back rib structures stitch diagrams: a - plated interlock, technical graph (connecting with more tuck points); $b$ - mini flat back rib - Technical graph (connecting with partial tuck points); $c$ - flat back rib - Technical graph (no connecting)

tigated for aerial density, thickness, air permeability, thermal conductivity, thermal resistance and wicking ability using standard testing methods.

\section{Physical properties of Eri silk bi-layer knitted fabrics}

Shirley thickness gauge machine is used to measure the fabric thickness in $\mathrm{mm}$ at different place of fabric, and areal density in $\mathrm{g} / \mathrm{m}^{2}$ and air permeability in $\mathrm{cm}^{3} / \mathrm{s} / \mathrm{cm}^{2}$ of the samples. The areal density of a twodimensional object is calculated as the mass per unit area and is expressed in Grams per Square Meter (GSM). The air permeability is measured by utilizing American Society for Testing and Materials D737 standard [27]. Physical characteristics are determined and mentioned in the tables 2 and 3.

Areal density

The results show that the areal density of the sample S1EB is found to be high among all the samples. It's confirmed that the areal density of the fabric is influenced by the structure and loop length of fabric.

A study between the yarn count and fabric areal density displays that the fabric areal density of $30 \mathrm{~s}$ yarn count is higher than $40 \mathrm{~s}$. This highlights that the fabric areal density of $0.3 \mathrm{~cm}$ loop length is better than the $0.4 \mathrm{~cm}$ loop length. When the raw material combination and fabric areal density were studied, Eri silk with bamboo and Eri silk with Tencel showed only slight variation in the fabric areal density. The fabric areal density was found to be superior for the plated interlock structure when compared to the mini flat back rib and flat back rib structures.

\section{Thickness}

The thickness results of all 24 samples showed slight variation and this was due to the fabric production using two different counts and two different loop lengths.

A comparison between the yarn count and thickness indicates that $30 \mathrm{~s}$ yarn count is better than $40 \mathrm{~s}$ yarn count. Very slight variations were found among $0.3 \mathrm{~cm}$ and $0.4 \mathrm{~cm}$ loop lengths when the loop length and thickness were studied. As the raw material combination and thickness are taken up for study, Eri silk with bamboo and Eri silk with Tencel were more or less the same. In very few cases Eri silk with Tencel was superior and in the rest Eri silk with bamboo was good. A study on the fabric structure and thickness revealed that the plated interlock structure possessed higher thickness followed by flat back rib structure. The mini flat back rib had the least thickness

\section{Air permeability}

The results of air permeability of fabric samples show that the samples S18ET, S24ET and S22ET have more air permeability when compared to all other 21 samples. Based on the result it is considered that the tightness factor and fabric structure had an influence on air permeability of the fabric samples.

A comparison between the yarn count and air permeability showed that the $40 \mathrm{~s}$ count had a higher air permeability than the $30 \mathrm{~s}$ count. The air permeability for $0.3 \mathrm{~cm}$ loop length was higher than that of $0.4 \mathrm{~cm}$ loop length. Results showed that Eri silk with Tencel exhibited higher air permeability than Eri silk with bamboo. A study between the fabric structure and air permeability insisted that the flat back rib structure and mini flat back rib structure had at times the same air permeability and at times the flat back rib had higher air permeability. The plated interlock had the least air permeability because of more tuck points in plated interlock structure.

\section{Thermal comfort properties of Eri bi-layer knitted fabrics}

NETZSCH HFM 436 testing instrument was used to measure the thermal properties of the fabrics, such as thermal conductivity and thermal resistance. The thermal resistance of clothing as a set of textile materials depends on the thickness and porosity of particular layer of the fabrics. The sample is kept between two plates (one is hot and another is cold) provided in the instrument, according to ISO 8301-1991/1: 2010 standards. 
SAMPLE CODE, YARN COUNT, FABRIC STRUCTURE, LOOP LENGTH AND STITCH DENSITY OF SAMPLES

\begin{tabular}{|c|c|c|c|c|c|}
\hline $\begin{array}{c}\text { Sample } \\
\text { no. }\end{array}$ & Sample code & Yarn count & Fabric structure & $\begin{array}{l}\text { Loop length } \\
\text { (cm) }\end{array}$ & $\begin{array}{l}\text { Stitch density } \\
\left(\text { loops } / \mathrm{cm}^{2}\right)\end{array}$ \\
\hline 1 & S1EB & $\begin{array}{c}\text { Eri silk - 16.7 Tex } \\
\text { Bamboo - 19.7 Tex }\end{array}$ & Plated interlock & $\begin{array}{l}\text { Inner }-0.31 \\
\text { Outer }-0.31\end{array}$ & $\begin{array}{l}\text { Inner - } 1053 \\
\text { Outer -1053 }\end{array}$ \\
\hline 2 & S2ET & $\begin{array}{l}\text { Eri silk - 16.7 Tex } \\
\text { Tencel - 19.7 Tex }\end{array}$ & Plated interlock & $\begin{array}{c}\text { Inner }-0.3 \\
\text { Outer }-0.31\end{array}$ & $\begin{array}{l}\text { Inner - } 1000 \\
\text { Outer - } 1000 \\
\end{array}$ \\
\hline 3 & S3EB & $\begin{array}{c}\text { Eri silk - 16.7 Tex } \\
\text { Bamboo - 19.7 Tex }\end{array}$ & Plated interlock & $\begin{array}{l}\text { Inner }-0.34 \\
\text { Outer }-0.34 \\
\end{array}$ & $\begin{array}{l}\text { Inner - } 864 \\
\text { Outer - } 864 \\
\end{array}$ \\
\hline 4 & S4ET & $\begin{array}{c}\text { Eri silk - 16.7 Tex } \\
\text { Tencel -19.7 Tex }\end{array}$ & Plated interlock & $\begin{array}{l}\text { Inner }-0.32 \\
\text { Outer }-0.33\end{array}$ & $\begin{array}{l}\text { Inner }-875 \\
\text { Outer }-875 \\
\end{array}$ \\
\hline 5 & S5EB & $\begin{array}{c}\text { Eri silk - 16.7 Tex } \\
\text { Bamboo - 19.7 Tex }\end{array}$ & Mini flat back rib & $\begin{array}{c}\text { Inner }-0.31 \\
\text { Outer }-0.4\end{array}$ & $\begin{array}{l}\text { Inner }-988 \\
\text { Outer }-532 \\
\end{array}$ \\
\hline 6 & S6ET & $\begin{array}{l}\text { Eri silk - 16.7 Tex } \\
\text { Tencel - 19.7 Tex } \\
\end{array}$ & Mini flat back rib & $\begin{array}{l}\text { Inner }-0.31 \\
\text { Outer }-0.39 \\
\end{array}$ & $\begin{array}{c}\text { Inner - } 1036 \\
\text { Outer - } 518 \\
\end{array}$ \\
\hline 7 & S7EB & $\begin{array}{c}\text { Eri silk - 16.7 Tex } \\
\text { Bamboo - 19.7 Tex }\end{array}$ & Mini flat back rib & $\begin{array}{l}\text { Inner }-0.30 \\
\text { Outer }-0.40\end{array}$ & $\begin{array}{l}\text { Inner - } 1118 \\
\text { Outer - 559 } \\
\end{array}$ \\
\hline 8 & S8ET & $\begin{array}{l}\text { Eri silk - 16.7 Tex } \\
\text { Tencel - 19.7 Tex }\end{array}$ & Mini flat back rib & $\begin{array}{l}\text { Inner }-0.30 \\
\text { Outer }-0.36\end{array}$ & $\begin{array}{c}\text { Inner - } 1134 \\
\text { Outer - } 588\end{array}$ \\
\hline 9 & S9EB & $\begin{array}{c}\text { Eri silk - 16.7 Tex } \\
\text { Bamboo - 19.7 Tex }\end{array}$ & Flat back rib & $\begin{array}{l}\text { Inner }-0.30 \\
\text { Outer }-0.38 \\
\end{array}$ & $\begin{array}{l}\text { Inner - } 1456 \\
\text { Outer - } 354 \\
\end{array}$ \\
\hline 10 & S10ET & $\begin{array}{c}\text { Eri silk - 16.7 Tex } \\
\text { Tencel -19.7 Tex } \\
\end{array}$ & Flat back rib & $\begin{array}{l}\text { Inner }-0.29 \\
\text { Outer }-0.43 \\
\end{array}$ & $\begin{array}{l}\text { Inner - } 1377 \\
\text { Outer - } 350 \\
\end{array}$ \\
\hline 11 & S11EB & $\begin{array}{c}\text { Eri silk - 16.7 Tex } \\
\text { Bamboo - 19.7 Tex }\end{array}$ & Flat back rib & $\begin{array}{l}\text { Inner }-0.32 \\
\text { Outer }-0.40\end{array}$ & $\begin{array}{c}\text { Inner - } 1300 \\
\text { Outer - } 312 \\
\end{array}$ \\
\hline 12 & S12ET & $\begin{array}{c}\text { Eri silk - 16.7 Tex } \\
\text { Tencel -19.7 Tex }\end{array}$ & Flat back rib & $\begin{array}{l}\text { Inner }-0.31 \\
\text { Outer }-0.45 \\
\end{array}$ & $\begin{array}{c}\text { Inner - } 1225 \\
\text { Outer - } 299 \\
\end{array}$ \\
\hline 13 & S13EB & $\begin{array}{c}\text { Eri silk - 14.3 Tex } \\
\text { Bamboo - 14.8 Tex }\end{array}$ & Plated interlock & $\begin{array}{l}\text { Inner }-0.31 \\
\text { Outer }-0.31\end{array}$ & $\begin{array}{l}\text { Inner - } 1040 \\
\text { Outer - } 1040\end{array}$ \\
\hline 14 & S14ET & $\begin{array}{l}\text { Eri silk - 14.3 Tex } \\
\text { Tencel - 14.8 Tex } \\
\end{array}$ & Plated interlock & $\begin{array}{l}\text { Inner }-0.33 \\
\text { Outer }-0.33 \\
\end{array}$ & $\begin{array}{l}\text { Inner - } 884 \\
\text { Outer - } 884 \\
\end{array}$ \\
\hline 15 & S15EB & $\begin{array}{c}\text { Eri silk - 14.3 Tex } \\
\text { Bamboo-14.8 Tex }\end{array}$ & Plated interlock & $\begin{array}{l}\text { Inner }-0.33 \\
\text { Outer }-0.33 \\
\end{array}$ & $\begin{array}{l}\text { Inner }-840 \\
\text { Outer - } 840 \\
\end{array}$ \\
\hline 16 & S16ET & $\begin{array}{l}\text { Eri silk - 14.3 Tex } \\
\text { Tencel - 14.8 Tex }\end{array}$ & Plated interlock & $\begin{array}{l}\text { Inner }-0.34 \\
\text { Outer }-0.34\end{array}$ & $\begin{array}{l}\text { Inner }-816 \\
\text { Outer }-816 \\
\end{array}$ \\
\hline 17 & S17EB & $\begin{array}{c}\text { Eri silk - 14.3 Tex } \\
\text { Bamboo - 14.8 Tex }\end{array}$ & Mini flat back rib & $\begin{array}{l}\text { Inner }-0.31 \\
\text { Outer }-0.42 \\
\end{array}$ & $\begin{array}{l}\text { Inner }-980 \\
\text { Outer }-490 \\
\end{array}$ \\
\hline 18 & S18ET & $\begin{array}{l}\text { Eri silk - 14.3 Tex } \\
\text { Tencel - 14.8 Tex }\end{array}$ & Mini flat back rib & $\begin{array}{l}\text { Inner }-0.3 \\
\text { Outer }-0.4 \\
\end{array}$ & $\begin{array}{l}\text { Inner }-980 \\
\text { Outer - } 490 \\
\end{array}$ \\
\hline 19 & S19EB & $\begin{array}{c}\text { Eri silk - 14.3 Tex } \\
\text { Bamboo - 14.8 Tex }\end{array}$ & Mini flat back rib & $\begin{array}{l}\text { Inner }-0.29 \\
\text { Outer }-0.37\end{array}$ & $\begin{array}{c}\text { Inner - } 1120 \\
\text { Outer - } 560\end{array}$ \\
\hline 20 & S20ET & $\begin{array}{l}\text { Eri silk - 14.3 Tex } \\
\text { Tencel - 14.8 Tex }\end{array}$ & Mini flat back rib & $\begin{array}{c}\text { Inner }-0.3 \\
\text { Outer }-0.40 \\
\end{array}$ & $\begin{array}{c}\text { Inner - } 1320 \\
\text { Outer - } 660 \\
\end{array}$ \\
\hline 21 & S21EB & $\begin{array}{c}\text { Eri silk - 14.3 Tex } \\
\text { Bamboo-14.8 Tex }\end{array}$ & Flat back rib & $\begin{array}{l}\text { Inner }-0.27 \\
\text { Outer }-0.47 \\
\end{array}$ & $\begin{array}{c}\text { Inner - } 1410 \\
\text { Outer - } 360 \\
\end{array}$ \\
\hline 22 & S22ET & $\begin{array}{l}\text { Eri silk - 14.3 Tex } \\
\text { Tencel - 14.8 Tex }\end{array}$ & Flat back rib & $\begin{array}{l}\text { Inner }-0.30 \\
\text { Outer }-0.48\end{array}$ & $\begin{array}{c}\text { Inner - } 1400 \\
\text { Outer - } 350\end{array}$ \\
\hline 23 & S23EB & $\begin{array}{c}\text { Eri silk - 14.3 Tex } \\
\text { Bamboo - 14.8 Tex }\end{array}$ & Flat back rib & $\begin{array}{l}\text { Inner }-0.29 \\
\text { Outer }-0.49 \\
\end{array}$ & $\begin{array}{c}\text { Inner - } 1260 \\
\text { Outer - } 308 \\
\end{array}$ \\
\hline 24 & S24ET & $\begin{array}{l}\text { Eri silk - 14.3 Tex } \\
\text { Tencel - 14.8 Tex }\end{array}$ & Flat back rib & $\begin{array}{l}\text { Inner }-0.32 \\
\text { Outer - } 0.49\end{array}$ & $\begin{array}{c}\text { Inner - } 1248 \\
\text { Outer - } 286\end{array}$ \\
\hline
\end{tabular}

Thermal conductivity is a property of fabrics that expresses the heat flux that will flow through the fabric if a certain temperature gradient exists over the material [28]. The thermal conductivity and thermal resistances of the fabric samples are mentioned in table 3.

\section{Thermal conductivity}

Based on the results it is understood that there are significant variations in the fabric thermal conductivity and it depends on the fabric structure, count of yarn, loop length and density of the fabric. The sample S1EB has more thermal conductivity compared to all other 23 samples. 
FABRIC AREAL DENSITY, THICKNESS, AIR PERMEABILITY, THERMAL CONDUCTIVITY AND THERMAL RESISTANCES OF THE FABRIC SAMPLES

\begin{tabular}{|c|c|c|c|c|c|c|}
\hline $\begin{array}{c}\text { Sample } \\
\text { no. }\end{array}$ & Sample code & $\begin{array}{c}\text { Fabric areal } \\
\text { density } \\
\left(G / M^{2}\right)\end{array}$ & $\begin{array}{l}\text { Thickness } \\
\text { (mm) }\end{array}$ & $\begin{array}{l}\text { Air permeability } \\
\left(\mathrm{cm}^{3} / \mathrm{s} / \mathrm{cm}^{2}\right)\end{array}$ & $\begin{array}{c}\text { Thermal } \\
\text { conductivity } \\
\text { (W/M-k*10-3) }\end{array}$ & $\begin{array}{c}\text { Thermal } \\
\text { resistance } \\
\left(\mathrm{M}^{2 *} \mathrm{k} / \mathrm{w}^{*} 10^{-3}\right)\end{array}$ \\
\hline 1 & S1EB & 334 & 1.19 & 35.9 & 15.87 & 57.35 \\
\hline 2 & S2ET & 332 & 1.26 & 42.4 & 11.55 & 80.01 \\
\hline 3 & S3EB & 310 & 1.28 & 55.6 & 14.52 & 52.47 \\
\hline 4 & S4ET & 293 & 1.22 & 54.4 & 10.56 & 73.20 \\
\hline 5 & S5EB & 231 & 1.07 & 67.4 & 13.15 & 55.80 \\
\hline 6 & S6ET & 228 & 1.11 & 108.0 & 12.92 & 55.74 \\
\hline 7 & S7EB & 250 & 1.05 & 84.8 & 11.83 & 50.22 \\
\hline 8 & S8ET & 237 & 1.01 & 98.6 & 11.62 & 50.16 \\
\hline 9 & S9EB & 239 & 1.18 & 97.5 & 13.19 & 59.90 \\
\hline 10 & S10ET & 233 & 1.22 & 108.0 & 13.00 & 59.21 \\
\hline 11 & S11EB & 245 & 1.19 & 99.5 & 11.87 & 53.91 \\
\hline 12 & S12ET & 238 & 1.21 & 107.0 & 11.70 & 53.28 \\
\hline 13 & S13EB & 254 & 0.98 & 47.6 & 13.07 & 55.12 \\
\hline 14 & S14ET & 237 & 1.05 & 59.8 & 12.40 & 54.62 \\
\hline 15 & S15EB & 215 & 0.98 & 71.8 & 11.56 & 48.78 \\
\hline 16 & S16ET & 229 & 1.07 & 98.9 & 10.97 & 48.33 \\
\hline 17 & S17EB & 190 & 1.08 & 122.0 & 12.13 & 55.23 \\
\hline 18 & S18ET & 163 & 0.98 & 166.0 & 10.35 & 55.06 \\
\hline 19 & S19EB & 179 & 1.01 & 134.0 & 10.79 & 49.15 \\
\hline 20 & S20ET & 205 & 1.07 & 108.0 & 9.21 & 49.00 \\
\hline 21 & S21EB & 180 & 1.04 & 128.0 & 10.28 & 55.46 \\
\hline 22 & S22ET & 158 & 0.96 & 167.0 & 9.45 & 55.01 \\
\hline 23 & S23EB & 190 & 1.05 & 134.0 & 9.09 & 49.08 \\
\hline 24 & S24ET & 162 & 0.98 & 160.0 & 8.36 & 48.68 \\
\hline
\end{tabular}

Note: E - Eri silk yarn, B - Bamboo yarn, T - Tencel yarn.

The comparison between yarn count and thermal conductivity displayed that $30 \mathrm{~s}$ yarn count had superior thermal conductivity than the $40 \mathrm{~s}$ count. The thermal conductivity of $0.3 \mathrm{~cm}$ loop length was higher than the $0.4 \mathrm{~cm}$ loop length. Eri silk with bamboo possessed higher thermal conductivity when compared with that of Eri silk with Tencel. The thermal conductivity of the plated interlock structure is higher when compared to mini flat back rib structure and flat back rib structure.

\section{Thermal resistance}

The thermal resistance of the sample S2ET was very high when compared to all other samples. The combination of Eri silk and Tencel yarn with different structures have an influence on thermal resistance.

A study on the yarn count and thermal resistance indicated that the $30 \mathrm{~s}$ yarn count had higher thermal resistance than the $40 \mathrm{~s}$ yarn count. It was observed that the thermal resistance of $0.3 \mathrm{~cm}$ loop length was better than $0.4 \mathrm{~cm}$ loop length. A study on the raw material combination and thermal resistance showed that Eri silk with Tencel had higher resistance for some samples and in the rest of the samples the thermal resistance was the same for both the combinations. Studies on the fabric structure and thermal resistance showed that the plated interlock structure had higher thermal resistance in few cases and the same thermal resistance in most of the cases.

\section{Wicking behaviour of Eri bi-layer knitted fabrics}

The moisture and thermal properties were affected by the fabrics wetting and wicking characteristics as in table 4 [29-32]. The specimens were cut along the wale-wise and course-wise directions $(250 \mathrm{~mm} \times 30$ $\mathrm{mm}$ ), which suspended vertically with its bottom edge of $5 \mathrm{~mm}$ immersed in a reservoir of distilled water The wicking heights were measured and recorded at regular intervals for 10 minutes to evaluate the wicking ability.

\section{Wicking behaviour (Course wise)}

The results show that the fabric sample S18ET has highest level of $16 \mathrm{~cm}$ wicking ability course wise for 10 minutes of time interval.

A comparison between the yarn count and course wise vertical wicking showed that the vertical wicking was maximum for $40 \mathrm{~s}$ count-10 minutes. A study between the loop length and course wise vertical 


\begin{tabular}{|c|c|c|c|c|c|c|c|c|c|}
\hline \multicolumn{10}{|c|}{ WICKING BBEHAVIOUR OF FABRIC SAMPLES } \\
\hline \multirow{2}{*}{$\begin{array}{c}\text { Sample } \\
\text { no. }\end{array}$} & \multirow{2}{*}{$\begin{array}{c}\text { Sample } \\
\text { code }\end{array}$} & \multicolumn{4}{|c|}{ Course wise $(\mathrm{cm})$} & \multicolumn{4}{|c|}{ Wales wise $(\mathrm{cm})$} \\
\hline & & $1 \mathrm{~min}$ & $3 \mathrm{~min}$ & $5 \mathrm{~min}$ & $10 \mathrm{~min}$ & $1 \mathrm{~min}$ & $3 \mathrm{~min}$ & $5 \mathrm{~min}$ & $10 \mathrm{~min}$ \\
\hline 1 & S1EB & 4.7 & 7.0 & 8.5 & 10.1 & 6.1 & 8.2 & 9.9 & 12.0 \\
\hline 2 & S2ET & 4.6 & 6.5 & 7.8 & 9.8 & 6.0 & 7.2 & 9.0 & 10.9 \\
\hline 3 & S3EB & 4.7 & 7.0 & 8.4 & 10.2 & 5.7 & 8.5 & 10.4 & 12.4 \\
\hline 4 & S4ET & 3.2 & 4.5 & 6.6 & 8.2 & 5.0 & 6.7 & 8.9 & 10.4 \\
\hline 5 & S5EB & 5.8 & 8.3 & 10.1 & 11.6 & 5.2 & 7.0 & 8.9 & 10.1 \\
\hline 6 & S6ET & 4.2 & 6.4 & 7.6 & 9.2 & 4.2 & 6.4 & 7.5 & 8.8 \\
\hline 7 & S7EB & 7.0 & 9.2 & 10.3 & 12.7 & 7.2 & 9.5 & 10.5 & 12.4 \\
\hline 8 & S8ET & 6.8 & 9.0 & 10.3 & 12.5 & 6.5 & 8.8 & 9.8 & 12.0 \\
\hline 9 & S9EB & 4.9 & 7.0 & 8.8 & 10.8 & 5.4 & 7.2 & 9.2 & 11.0 \\
\hline 10 & S10ET & 5.9 & 7.0 & 8.2 & 9.7 & 6.9 & 7.8 & 10.0 & 12.8 \\
\hline 11 & S11EB & 5.8 & 7.8 & 9.3 & 11.9 & 6.3 & 8.0 & 9.8 & 12.4 \\
\hline 12 & S12ET & 6.4 & 7.9 & 9.2 & 11.1 & 7.1 & 9.1 & 10.5 & 12.8 \\
\hline 13 & S13EB & 5.3 & 7.7 & 9.5 & 12.8 & 6.1 & 8.6 & 10.8 & 13.9 \\
\hline 14 & S14ET & 7.2 & 10.0 & 12.1 & 14.4 & 6.8 & 9.2 & 11.0 & 13.6 \\
\hline 15 & S15EB & 5.4 & 7.7 & 10.6 & 12.8 & 5.6 & 7.3 & 10.2 & 12.3 \\
\hline 16 & S16ET & 4.0 & 6.4 & 8.4 & 11.8 & 4.4 & 6.5 & 8.8 & 12.2 \\
\hline 17 & S17EB & 7.0 & 9.7 & 11.2 & 13.8 & 5.7 & 8.4 & 10.1 & 12.2 \\
\hline 18 & S18ET & 7.2 & 9.8 & 13.0 & 16.1 & 5.4 & 8.6 & 12.2 & 15.3 \\
\hline 19 & S19EB & 6.1 & 10.0 & 12.2 & 14.6 & 5.0 & 8.0 & 10.5 & 13.0 \\
\hline 20 & S20ET & 6.4 & 8.4 & 10.2 & 12.5 & 5.8 & 7.9 & 9.0 & 11.4 \\
\hline 21 & S21EB & 5.5 & 8.9 & 10.7 & 13.2 & 6.0 & 9.4 & 11.1 & 13.6 \\
\hline 22 & S22ET & 6.7 & 9.0 & 11.5 & 14.5 & 6.0 & 8.5 & 10.9 & 13.7 \\
\hline 23 & S23EB & 5.8 & 7.7 & 9.5 & 11.1 & 5.3 & 7.3 & 9.9 & 11.4 \\
\hline 24 & S24ET & 6.8 & 9.4 & 11.5 & 14.0 & 6.0 & 9.0 & 10.7 & 13.2 \\
\hline
\end{tabular}

Note: E - Eri silk yarn, B - Bamboo yarn, T - Tencel yarn.

wicking showed that the vertical wicking was at maximum for $0.3 \mathrm{~cm}$ loop length- 10 minutes and then it was noticed high in $0.4 \mathrm{~cm}$ loop length-10 minutes. The raw material combination and course wise vertical wicking clearly showed that Eri silk with Tencel combination 10 minutes possessed higher vertical wicking in few samples and in the rest of the samples Eri silk with bamboo combination-10 minutes had the highest vertical wicking. The course wise vertical wicking was the highest in the mini flat back rib-10 minutes.

\section{Wicking behaviour (Wales wise)}

The results show that the fabric sample S18ET has highest level of $15 \mathrm{~cm}$ wicking ability wales wise for 10 minutes of time interval.

The vertical wicking wales wise was observed to be highest for $40 \mathrm{~s}$ count-10 minutes. A study between the loop length and vertical wicking emphasized that the vertical wicking was highest in $0.3 \mathrm{~cm}$ loop length-10 minutes and then it was better in $0.4 \mathrm{~cm}$ loop length-10 minutes. The raw material combination and wales wise vertical wicking study showed that the Eri silk with Tencel combination-10 minutes had highest vertical wicking. Eri silk with bamboo combination-10 minutes had the highest vertical wicking. A study between the fabric structure and wales wise vertical wicking showed that the vertical wicking was highest in mini flat back rib-10 minutes and then in flat back rib-10 minutes.

\section{Effect of raw material combination}

The effect of different raw material on fabric areal density, air permeability thermal conductivity and thermal resistance has been studied and recorded. The areal density of fabric which is manufactured by Eri silk and bamboo yarn gains more areal density as the combination of Eri silk and Tencel gained less. The air permeability of the fabric made using Eri silk and Tencel is more as compared to the fabric made using Eri silk and bamboo.

\section{Effect of yarn count combination}

The effect of two different yarn counts of Eri silk, bamboo and Tencel on fabric areal density, air permeability thermal conductivity and thermal resistance has been studied and recorded. The fabric made with Eri silk-16.7 Tex, bamboo/Tencel-19.7 Tex yarns have good areal density when compared to the fabrics made with Eri silk-14.3 Tex, bamboo/Tencel-14.8 Tex 
yarns. The air permeability of the fabric produced using Eri silk-14.3 Tex, bamboo/Tencel-14.8 Tex yarns have better results than the fabrics made of Eri silk-14.3 Tex, bamboo/Tencel-14.8 Tex yarn. Thermal conductivity of fabric manufactured using Eri silk-16.7 Tex, bamboo/Tencel-19.7 Tex yarns are greater than the other fabrics made with Eri silk-14.3 Tex, bamboo/Tencel-14.8 Tex yarn. The resistance of the fabrics made with Eri silk-14.3 Tex, bamboo/Tencel-14.8 Tex yarn are less as compared to the fabrics made with Eri silk-16.7 Tex, bamboo/Tencel-19.7 Tex yarns.

\section{Effect of fabric structure combination}

The effect of fabric structures such as plated interlock, mini flat back rib and flat back rib on the fabric areal density, air permeability, thermal conductivity and thermal resistance has been studied and recorded. Based on the results the fabric areal density, thermal conductivity thermal resistance of the fabric knitted using plated interlock structure were more when compared to mini flat back rib and flat back rib structured fabrics. The air permeability of plated interlock structure fabric was less when compared to mini flat back rib and flat back rib structured fabrics.

\section{Effect of loop length combination}

The effect of two different loop lengths such as $0.3 \mathrm{~cm}$ and $0.4 \mathrm{~cm}$ on the fabric areal density, air permeability, thermal conductivity and thermal resistance has been studied and recorded. The results show that the areal density and thermal conductivity of fabrics produced using the loop length of $0.3 \mathrm{~cm}$ are more when compared to the fabrics produced using the loop length of $0.4 \mathrm{~cm}$. The air permeability and thermal resistance of the fabric made using $0.4 \mathrm{~cm}$ are higher than that of the fabrics made using $0.3 \mathrm{~cm}$ loop length.

\section{REGRESSION ANALYSIS}

A relationship between the fabric areal density and air permeability was studied. The trend of the linear line clearly indicates the change in air permeability. The $R^{2}$ value $(0.8001)$ shows that the change is great for the fit. The change in the fabric areal density is responsible for the variations in the air permeability. The $80 \%$ change in the air permeability is due to changes in the fabric areal density (table 5).

The relationship between fabric areal density and thermal conductivity of Eri silk bilayer knitted fabrics were plotted for regression. The $R^{2}$ value $(0.4744)$ indicates that the fit is slightly less. The $47 \%$ change in the thermal conductivity is due to changes in the fabric areal density.

A relationship between fabric areal density and thermal resistance of Eri silk bilayer knitted fabrics was studied. It was observed from the graph that the $R^{2}$ value (0.3178) exhibited a very low fit. Hence the thermal resistance with respect to the fabric areal density is low. The $31 \%$ change in the thermal resistance is due to changes in the fabric areal density.
Table 5

\begin{tabular}{|c|l|c|}
\hline \multicolumn{3}{|c|}{ REGRESSION RELATIONSHIP } \\
\hline $\begin{array}{c}\text { Sample } \\
\text { no. }\end{array}$ & \multicolumn{1}{|c|}{ Regression relationship } & $R^{2}$ value \\
\hline 1 & $\begin{array}{l}\text { Relationship between fabric areal } \\
\text { density and air permeability }\end{array}$ & 0.8001 \\
\hline 2 & $\begin{array}{l}\text { Relationship between fabric areal } \\
\text { density and thermal conductivity }\end{array}$ & 0.4744 \\
\hline 3 & $\begin{array}{l}\text { Relationship between fabric areal } \\
\text { density and thermal resistance }\end{array}$ & 0.3178 \\
\hline 4 & $\begin{array}{l}\text { Relationship between thickness } \\
\text { and air permeability }\end{array}$ & 0.2626 \\
\hline 5 & $\begin{array}{l}\text { Relationship between thickness } \\
\text { and thermal conductivity }\end{array}$ & 0.2599 \\
\hline 6 & $\begin{array}{l}\text { Relationship between thickness } \\
\text { and thermal resistance }\end{array}$ & 0.3339 \\
\hline 7 & $\begin{array}{l}\text { Relationship between stitch density } \\
\text { and air permeability }\end{array}$ & 0.2604 \\
\hline 8 & $\begin{array}{l}\text { Relationship between stitch density } \\
\text { and thermal conductivity }\end{array}$ & 0.0869 \\
\hline 9 & $\begin{array}{l}\text { Relationship between stitch density } \\
\text { and thermal resistance }\end{array}$ & 0.0118 \\
\hline
\end{tabular}

The thickness and air permeability of Eri silk bilayer knitted fabrics was observed and the fit for regression was plotted on the graph. On observing the $R^{2}$ value $(0.2626)$ it is concluded that air permeability with respect to fabric areal density is very low. The $26 \%$ change in the air permeability is due to changes in the fabric thickness.

A relationship between thickness and thermal conductivity of Eri silk bilayer knitted fabrics was interpreted. The $R^{2}$ value $(0.2599)$ gave a clear picture indicating that the fit between both is very less. The thickness is responsible for the same. The $25 \%$ change in the thermal conductivity is due to changes in the fabric thickness.

The thermal resistance for Eri silk bilayer knitted fabrics with respect to thickness was studied. The regression fit plotted for the graph showed that the $R^{2}$ value $(0.3339)$ is slightly less. Hence the thermal resistance is affected due to its thickness. The $33 \%$ change in the thermal resistance is due to changes in the fabric thickness.

The relationship between the stitch density and air permeability of Eri silk bi layer knitted fabrics was interpreted. The results were plotted for the regression fit on the graph. The interpreted $R^{2}$ value (0.2604) mentioned that the fit possessed a very less regression value. The $26 \%$ change in the air permeability is due to changes in the fabric stitch density.

A study between the stitch density and thermal conductivity was taken up and the results were fitted for regression. The obtained $R^{2}$ value $(0.0869)$ showed that regressive fit is very low. Hence the thermal conductivity is influenced by stitch density. The $8 \%$ change in the thermal conductivity is due to changes in the fabric stitch density. 
The relationship between the thermal resistance and stitch density was studied and the regressive fit was done. The acquired $R^{2}$ value $(0.0118)$ proved the regressive fit to be very less. Thus thermal resistance is found to be influenced by stitch density. The $1 \%$ change in the thermal resistance is due to changes in the fabric stitch density.

\section{CONCLUSION}

Loop length and fabric structure has significant influence on the fabric physical properties such as fabric areal density, thickness and air permeability. Fabric samples of S18ET, S24ET and S22ET has higher air transmission rate, due to openness created by fabric structures. The air permeability of the bi-layer fabric increases when the thickness of fabric decreases with more openness in the fabric. The Eri silk-bamboo bi-layered fabrics has better thermal resistance than equivalent Eri-Tencel fabrics, due to high areal density as well as thermal insulation properties of materials. The wicking characteristics of the bi-layer fabrics were highly influenced by thickness. It is concluded from the study that the bi-layer Eri silk with bamboo has good thermal comfort property than Tencel layered fabrics, besides layered fabrics with more tuck-points provides better thermal comfort properties.

\section{REFERENCES}

[1] Morris, G.J., Thermal Properties of Textile Materials, In: Journal of the Textile Institute Transactions, 1953, 44, 10, 449-476

[2] Stankovic, B.S., Popovic, D., Poparic, G.B., Thermal Properties of Textile Fabrics Made of Natural and Regenerated Cellulose Fibers, In: Polymer Testing, Elsevier, 2008, 27, 41

[3] Jirsak, O., Thermo Elastic Properties of Perpendicular Laid versus Cross Laid Lofty Non Woven Fabrics, In: Textile Research Journal, 2000, 20, 121

[4] Slater, K., Comfort Properties of Textiles, The Textile Institute, Manchester, England, 1977, 11

[5] Ishtiaque, S.M., Engineering comfort, Proceedings on Smart Textiles, their Production and Market Strategies, NIFT, New Delhi, India, 2000, 58

[6] Umbach, K.H., Aspects of Clothing Physiology in the Development of Sportswear, In: Knitting Technique, 1993, 15, 165

[7] Silva, A.P., Anand, S.C., Responsive Garments for Sportswear, Proceedings on smart Textiles, their Production and Market Strategies, NIFT, New Delhi, India, 2000, 32

[8] Sule, A.D., Bardhan, M.K., Sarkar, R.K., Development of Sportswear for Indian Conditions, In: Man Made Textiles in India, 2004, 123

[9] Sathish Babu, B., Senthilkumar, P., Senthilkumar, M., Effect of Yarn Linear Density on Moisture Management CharactEristics of Cotton/Polypropylene Double Layer Knitted Fabrics, In: Industria Textila, 2015, 66, 123

[10] Kyatuheire, S., Wei, L., Mwasiagi, J.I., Investigation of Moisture Transportation Properties of Knitted Fabrics Made from Viscose Vortex Spun Yarns, In: Fibers and Textiles in Eastern Europe, 2014, 9, 151

[11] Kandhavadivu, P., Rathinamoorthy, R., Surjit, R., Moisture and Thermal Management Properties of Woven and Knitted Tri-layer Fabrics, In: Indian Journal of Fiber and Textile Research, 2015, 40, 243

[12] Troynikov, O., Wardiningsih, W., Moisture Management Properties of Wool/Polyester and Wool/bamboo Knitted Fabrics for the Sportswear Base Layer, In: Textile Res. Journal, 2011, 81, 621

[13] Piller, B., Integrated Multi-layered Knitted Fabrics - A New Generation of Textiles Polypropylene Fibers, In: Melliand Textilber, 1986, 67, 412

[14] Ajay, R., Avinash, K., Physical and UV Protection Properties of Knitted Bamboo Fabrics, In: Textile Review, 2012, 7,24

[15] Senthil Kumar, B., Ramachandran, T., Influence of Knitting Process Parameters on the Thermal Comfort Properties of Eri Silk Knitted Fabrics, In: Fibers and Textiles in Eastern Europe, 2018, 5, 47

[16] Kariyappa, Shivkumar, K.P., Rao, Evaluation of Physical and Comfort Properties of Eri and Wool Spun Yarn Woven Fabrics, In: Man Made Textile in India, 2009, 393

[17] Brojeswari Das, N., Padaki, V., Jaganathan, K., Studies on Comfort Properties of Eri silk Wool Blended Fabrics for Winter Wear Applications, $24^{\text {th }}$ International Congress of ISC on Sericulture and silk industry, Bangkok, Thailand, 2016, 10

[18] Onofrei, E., Rocha, A.M., Catarino, A., The Influence of Knitted Fabrics' Structure on The Thermal and Moisture Management Properties. In: Journal of Engineered Fibers and Fabrics, 2011, 6, 10

[19] Morton, W.W.E., Hearle, J.W.S., Physical Properties of Textile Fibers, Woodhead Publishing Ltd., Cambridge, England, 2008

[20] Sen, K., Murugesh, K., Babu, Studies on Indian silk. I. Macro characterization and Analysis of Amino Acid Composition, In: Journal of Applied Polymer Science, 2004, 92, 1080-1097

[21] Ogulata, R.T., Mavruz, S., Investigation of Porosity and Air Permeability Values of Plain Knitted Fabrics, In: Fibers \& Textiles in Eastern Europe, 2010, 5, 82, 71-75

[22] Brojeswari Das, N., Padaki, V., Jaganathan, K., Naik, S.V., Studies on Comfort Properties of Eri Silk and Wool Blended Fabrics for Winter Wear Applications, Silk for the green world and sustainable development, Central Silk Technological Research Institute, Central Silk Board, Bangalore, India, 1 
[23] Kulkarni, P.R., Bahuguni, R.S., Optimum Machinery, process and products for Eri silk /wool blends, In: Wool Tech, 2011, 1

[24] Kumar De, S., Ashis, M., A Study of Some Mechanical Properties of Eri Fabric and Comparative Study with Wool Fabric, In: Man-Made Textiles in India, 2013, 41, 162

[25] Chidambaram, P., Govindan, R., Venkatraman, K.C., Study of Thermal Comfort Properties of Cotton/Regenerated Bamboo Knitted Fabrics, In: African Journal of Basic and Applied Sciences, 2012, 4, 61

[26] Üstüntağ, S., Çarkıt, G., Turksoy, H.G., Thermal Comfort Properties of Fabrics Knitted from Bamboo/Cotton Blended Yarns, In: Journal of Science and Engineering, 2017, 19, 510

[27] Standard Test Method for Air Permeability of Textile Fabrics, Active Standard ASTM Developed by Subcommittee, ASTM International

[28] Farnworth, B., Mechanisms of Heat Flow through Clothing Insulation, In: Textile Research Journal, 1983, 53, 717

[29] Bagherzadeh, R., Gorji, M., Latifi, M., Payvandy, P., Kong, L.X., Evolution of moisture management behavior of high-wicking 3D warp knitted spacer fabrics, In: Fiber Polym. 2012, 529

[30] M 290 MMT Instruction Manual version 4.0, www.sdlatlas.com

[31] Gorji, M., Bagherzade, R., Fashandi, H., Electrospun Nano Fibers, M. Afshari Elsevier, 2016, 567

[32] Gorji, M., JeddiAli, A.A., Gharehaghaji, A., Fabrication and characterization of polyurethane electrospun nanofiber membranes for protective clothing applications, In: Journal Applied Polymer Science, 2012, 125, 41

\author{
Authors: \\ SATHISH T. KUMAR ${ }^{1}$, RAMESH M. KUMAR ${ }^{1}$, SENTHIL B. KUMAR ${ }^{2}$ \\ ${ }^{1}$ Department of Fashion Technology, Sona College of Technology, Salem - 636005, Tamilnadu, India \\ e-mail: ramesh@sonatech.ac.in \\ ${ }^{2}$ Head Centre for Apparel Research and Education, NIFT TEA Knitwear Fashion Institute, \\ Tirupur - 641 606, Tamilnadu, India \\ e-mail: bsenthilkumar_123@yahoo.co.in

\section{Corresponding author:} \\ SATHISH T. KUMAR \\ e-mail: sathishresearch580@gmail.com
}

